\title{
PERAN SUAMI DALAM PERAWATAN KEHAMILAN ISTRI DI KELURAHAN MULYOREJO
}

\author{
Imroatul Hasanah ${ }^{1}$, Nurul Fitriyah ${ }^{2}$ \\ ${ }^{1,2}$ Departemen Biostatistika dan Kependudukan \\ Fakultas Kesehatan Masyarakat Universitas Airlangga \\ J1. Mulyorejo Kampus C Mulyorejo Surabaya 601115 \\ Alamat Korespondesi: Imroatul Hasanah \\ Email: imroatul.hasanah-2014@fkm.unair.ac.id
}

\begin{abstract}
National health development strategy has resulted in improved public health status. One of indicators public health is Maternal Mortality Rate (MMR). Maternal Mortality Rate is a health problem that still many still occur in Indonesia. One factor contributing to high incidence of maternal mortality is lack of antenatal care attention. Antenatal care is an important and mandatory thing done by mother during pregnancy because it can maintain the health of mother and fetus until the birth process. Antenatal care can identify the risk of complications experienced by the mother during pregnancy. Participation of antenatal care not only from wife, but participation of pregnancy care can also be from support of the closest person is husband. Husband role is needed in the care of pregnancy because wife needs a lot of biological and psychological support. Purpose of research is to know characteristics husband to antenatal care in Mulyorejo. Type of research is descriptive with cross sectional using qualitative method. Techniques data collection using questionnaires with the sample number of respondents is 20 husbands who have pregnant wives. Respondent is taken from Mulyorejo Health Center data. Analysis Method with descriptive statistics by displaying the frequency in the form of tables showing the categories of characteristics husband. This study lasted for one month in October to November 2017. The results showed that characteristics of husbands in antenatal care in Mulyorejo is sufficient category. Knowledge of husband is 14 people (70\%), husband attitude is 10 people (50\%), and husband behavior is 13 people $(65 \%)$.
\end{abstract}

Keywords: woman pregnancy, husband, antenatal care

\begin{abstract}
ABSTRAK
Strategi pembangunan kesehatan nasional mewujudkan peningkatan status derajat kesehatan masyarakat. Salah satu acuan indikator kesehatan masyarakat adalah Angka Kematian Ibu (AKI). Angka Kematian Ibu merupakan masalah kesehatan yang masih banyak masih banyak terjadi di Indonesia. Salah satu faktor yang menyebabakan masih tingginya angka kejadian kematian ibu adalah kurangnya perhatian akan perawatan kehamilan. Perawatan kehamilan merupakan hal penting dan wajib yang dilakukan oleh ibu saat hamil karena dapat menjaga kesehatan ibu dan janin sampai proses persalinan. Perawatan kehamilan dapat mengidentifikasi risiko komplikasi yang dialami oleh ibu saat kehamilan. Partisispasi perawatan kehamilan tidak hanya dari diri istri yang hamil, namun partisipasi perawatan kehamilan juga dapat dari dukungan orang yang paling dekat yaitu suami. Peran suami sangat dibutuhkan dalam perawatan kehamilan karena seorang istri yang sedang hamil membutuhkan banyak dukungan secara biologis dan psikologis. Tujuan dari penelitian ini adalah untuk mengetahui peran suami dalam perawatan kehamilan istri di Kelurahan Mulyorejo Jenis penelitian ini adalah deskriptif dengan rancangan cross sectional. Pengambilan data menggunakan kuesioner dengan jumlah sampel responden adalah 20 orang suami yang memiliki istri hamil. Metode analisis dengan deskriptif statistik dengan menampilkan frekuensi yang ditampilkan dalam bentuk tabel yang menunjukkan kategori karakteristik suami. Penelitian ini berlangsung selama dua bulan pada bulan September hingga November 2017. Hasil penelitian menunjukkan bahwa peran suami dalam perawatan kehamilan istri di Kelurahan Mulyorejo mayoritas berada dalam kategori cukup untuk pengetahuan suami sebanyak 14 orang (70\%), sikap suami sebanyak 10 orang (50\%), dan perilaku suami 13 orang $(65 \%)$.
\end{abstract}

Kata kunci : suami, ibu hamil, perawatan kehamilan

\section{PENDAHULUAN}

Kematian ibu adalah kehamilan dalam periode 42 hari setelah berakhirnya kehamilan yang bisa terjadi karena disebabkan atau diperberat oleh kehamilannya atau karena penanganan yang dilakukan, namun bukan 
disebabkan oleh kejadian kecelakaan atau cedera saat kehamilan. Angka Kematian Ibu digunakan sebagai angka indikator yang peka akan penggambaran mengenai kesejahteraan masyarakat di suatu negara (Kemenkes RI, 2014).

Secara global, suatu negara mengacu pada target MDG's (Millenium Development Goals) merupakan target ke-5 dengan target menurunkan Angka Kematian Ibu sebesar 102 per 100.000 kelahiran hidup ditahun 2015. Angka Kematian Ibu (AKI) di Indonesia merupakan suatu masalah yang masih perlu dihadapi karena Indonesia tergolong memiliki jumlah angka kematian ibu tertinggi diantara negara asia (Saputra, 2013). Angka kematian ibu di Indonesia mencapai 359 per 100.000 kelahiran hidup hal ini mengalami sedikit penurunan dari tahun 1991 yaitu 390 per 100.000 kelahiran hidup (Kemenkes RI, 2014).

Kondisi tersebut menggambarkan bahwa perlu adanya tindakan kerja keras dan sungguh-sungguh untuk mencapai target sasaran MDGs dalam menurunkan angka kematian ibu di Indonesia karena angka kematian yang masih jauh dari target.

Penyumbang terbesar tingginya angka kematian ibu di Indonesia selama tahun 20122013 yaitu pendarahan. Selain itu penyebab terbesar lainnya kematian ibu yaitu penyebab secara tidak langsung. Penyebab secara tidak langsung yaitu seperti kondisi ibu hamil yang memiliki riwayat penyakit kanker, ginjal, jantung, tuberkulosis, atau penyakit lainnya yang diderita oleh ibu hamil (Kemenkes RI, 2014).

Angka Kematian Ibu di Jawa Timur cenderung mengalami penurunan sejak enam tahun terakhir tahun 2010-2015. Namun pada tahun 2016 Angka Kematian Ibu di Jawa Timur mengalami peningkatan dari tahun sebelumnya yaitu menjadi sebesar 91 per 100.000 kelahiran hidup. Capaian angka tersebut telah memenuhi target atau dibawah target Renstra yaitu 97,19 per 100.000 kelahiran penduduk. Meskipun angka kematian ibu telah memenuhi target Renstra dan MDGs, angka kematian ibu harus tetap diupayakan terus mengalami penurunan. Penyumbang terbesar kematian ibu di Jawa Timur tahun 2016 disebabkan oleh pre eklamsi dan eklamsi yaitu sebesar 30,90\% atau sebanyak 165 orang. Kejadian pre eklamsi dan eklamsi yang terjadi pada ibu hamil cenderung meningkat selama tiga tahun terakhir. Data yang didapatkan dari
Dinas Kesehatan Kota Surabaya di tahun 2016 angka kematian ibu mencapai 86 per 100.000 kelahiran hidup. Angka kematian tersebut berasal dari jumlah kematian ibu hamil, jumlah kematian ibu bersalin, dan jumlah kematian ibu nifas. Jumlah kematian ibu di Kota Surabaya paling banyak dialami oleh umur 20-34 tahun (Dinkes, 2017).

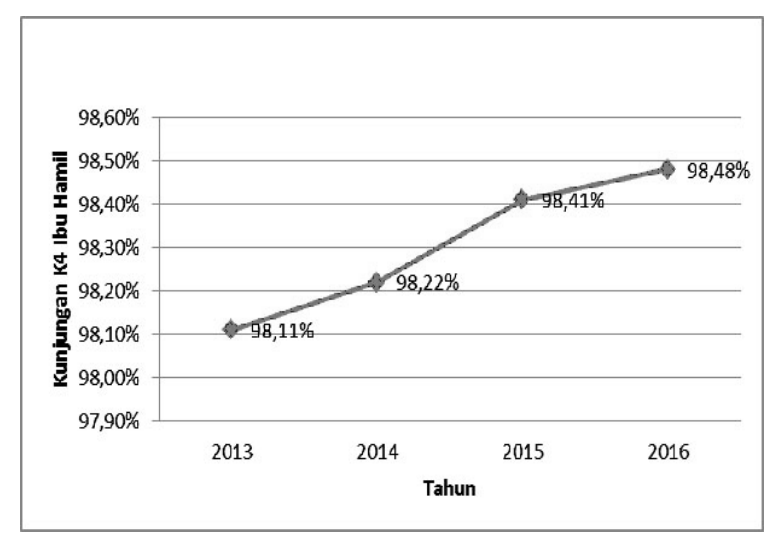

Gambar 1. Grafik Cakupan Kunjungan K4 Ibu Hamil Kota Surabaya Tahun 2013-2016

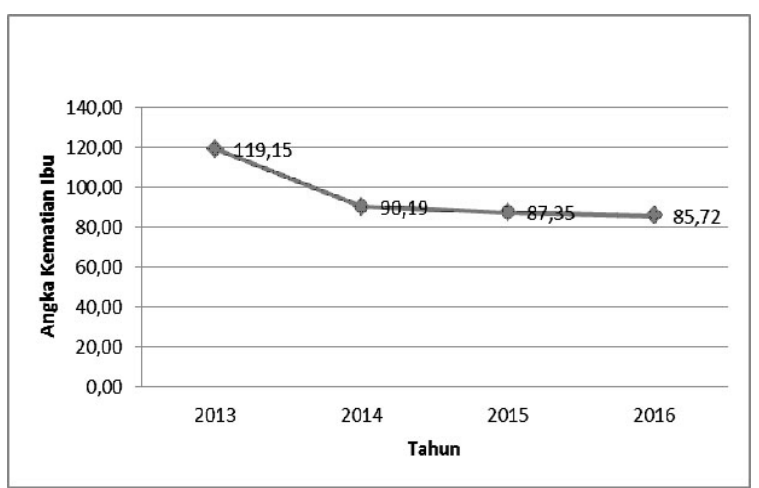

Gambar 2. Angka Kematian Ibu Tahun 20132016 di Kota Surabaya

Perawatan kehamilan pada ibu hamil merupakan hal yang penting dilakukan untuk mencegah terjadinya komplikasi dan kematian pada waktu masa kehamilan atau saat persalinan. Perawatan kehamilan yang perlu diperhatikan adalah perawatan diri, imunisasi, mengikuti kegiatan senam hamil, istirahat yang cukup, pemeriksaan kehamilan secara teratur, dan asupan gizi yang dibutuhkan oleh ibu hamil. Perawatan kehamilan dipengaruhi oleh beberapa faktor antara lain faktor predisposisi, faktor pendukung, dan faktor penguat. Beberapa faktor tersebut seperti pengetahuan tentang pemahaman cara perawatan kehamilan. Faktor-faktor lain yang ikut mempengaruhi perawatan kehamilan antara lain usia, 
pendidikan, pekerjaaan, paritas, dukungan sosial (suami, keluarga, tenaga kesehatan), dan ekonomi.

Kualitas dalam perawatan kehamilan dapat lebih baik dari dukungan keluarga yaitu pihak suami. Partisipasi dukungan yang diberikan oleh suami dapat berupa dukungan secara fisik maupun secara psikologis. Seorang suami dapat memberikan motivasi pada ibu hamil untuk melakukan pemeriksaan kehamilan ke pelayanan kesehatan secara teratur. Hal tersebut juga dapat sekaligus mendukung tercapainya tingkat kunjungan pemeriksaan kehamilan K1 dan K4 yang merupakan salah satu indikator program Antenatal Care (ANC). Penelitian yang dilakukan oleh Gamelia, et.al. (2013) bahwa variabel dominan yang paling mempengaruhi ibu hamil dalam melakukan perawatan kehamilan adalah peran suami. Hasil penelitian yang sama dilakukan oleh Istikhomah \& Emy (2014) bahwa ada hubungan yang antara pendampingan suami pada kunjungan ANC dengan tingkat kecemasan pada ibu hamil trisemester III. Faktor pengetahuan, pekerjaan, dan pendapatan suami juga memiliki hubungan dengan dukungan partisipasi suami dalam menjaga atau perawatan kehamilan istri berdasarkan penelitian yang dilakukan oleh Aprina (2017). Pelayanan ANC perlu dilakukan secara terpadu dengan memberikan program lain yang akan diterima oleh ibu hamil yang memerlukan intervensi selama kehamilannya. Pelayanan ANC secara terpadu memberikan pelayanan antenatal secara komprehensif dan berkualitas.

Ibu hamil yang tidak melakukan kunjungan ANC kemungkinan besar diakibatkan oleh kurangnya pengetahuan akan pentingnya antenatal care untuk melindungi kesehatan ibu dan bayi. Kondisi tersebut dipengaruhi oleh lingkungan yang kurang mendukung seperti ibu hamil lain yang tidak melakukan kunjungan antenatal care serta keluarga yang kurang mengingatkan untuk melakukan kunjungan antenatal.

Alasan lain mengapa ibu hamil tidak melaksanakan kunjungan antenatal care adalah fasilitas kesehatan kurang memadai. Fasilitas dan sarana prasarana yang kurang lengkap membuat ibu hamil yang melakukan kunjungan antenatal care merasa kurang nyaman. Petugas kesehatan yang bertugas memeriksa kandungan kadang juga memiliki sikap yang kurang ramah. Hal tersebut membuat informasi mengenai perkembangan kehamilan ibu menjadi kurang atau tidak lengkap.

Seringkali dijumpai kasus ibu hamil yang berkarir karena kesibukan pekerjaan, sehingga mereka kurang memperhatikan kunjungan antenatal care. Setelah pulang kerja, mereka kelelahan sehingga tidak sempat untuk pergi ke tempat pemeriksaan kehamilan. Faktor tersebut menyebabkan antenatal care masih belum menjadi prioritas bagi ibu hamil.

Selain itu, alasan mengapa ibu hamil tidak melakukan kunjungan antenatal care adalah karena jam periksa bentrok dengan jam kerja, keluarga acuh akan keadaan si ibu karena kehamilan dianggap proses alamiah, biaya pemeriksaan yang mahal bagi masyarakat yang berekonomi rendah, takut untuk pergi ke rumah sakit, serta pemeriksaan kehamilan yang dilakukan cukup sekali, sehingga tidak perlu tahu bagaimana perkembangan kehamilan berikutnya (Mukaromah \& Saenun, 2014).

Persentase hasil capaian K4 ibu hamil di tahun 2015 sampai pada bulan Mei di Puskesmas Mulyorejo mencapai 39\%. Hasil capaian dari Bulan Mei tahun 2015 mengenai kunjungan ibu hamil telah mengalami kenaikan dari tahun-tahun sebelumnya. Meskipun mengalami kenaikan di tiap tahunnya, capaian kunjungan K4 ibu hamil masih dibawah target yang telah ditetapkan (Usa, 2017).

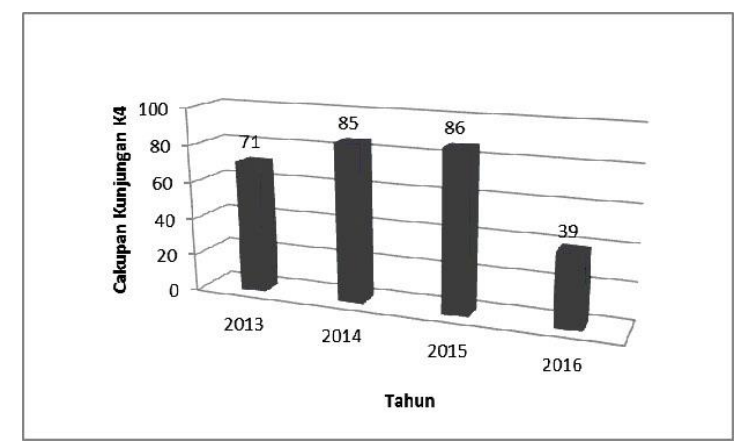

Gambar 3. Jumlah cakupan K4 Ibu hamil di Kelurahan Mulyorejo

Kenaikan angka cakupan K4 yang signifkan di Puskesmas Mulyorejo tiap tahunnya dikarenakan seiring dengan berjalannya kegiatan akselerasi penurunan kematian ibu yang mempengaruhi pemeriksaan Antenatal Care pada umumnya dilaksanakan dengan standar frekuensi pemeriksaan minimal 4 kali dalam periode selama kehamilan. Namun pelayanan ANC yang berlaku di Puskesmas Mulyorejo sudah tidak 
menggunakan standar minimal 4 kali pemeriksaan tetapi 12 kali periksa kehamilan atau disebut dengan K12. Periode periksa pada K12 yaitu pada trimester I melakukan pemeriksaan sebanyak 3 kali, trimester II 3 kali, dan trimester III sebanyak 6 kali. Puskesmas Mulyorejo tidak hanya melakukan pelayanan ANC , namun memberikan pelayanan ANC terpadu yaitu memberikan pelayanan secara lengkap dengan melibatkan seluruh tenaga kesehatan seperti dokter umum, dokter gigi, laborat, nutrisionist, bidan, dan petugas KB. Dokter umum untuk memeriksa general check up, dokter gigi untuk memeriksa gigi dan mulut dan mendeteksi adanya resiko pre eklamsi pada ibu hamil. Pemeriksaan lab untuk mengecek kesehatan ibu hamil berdasarkan kadar $\mathrm{Hb}$ normal, mengetahui golongan darah, pengecekan virus HIV AIDS, dan pengecekan protein urea (Yuni, 2010).

Selain mendapatkan dukungan dari petugas kesehatan yang membantu antenatal care, ibu hamil sendiri juga perlu mendapatkan dukungan kuat dari orang terdekat yaitu keluarga terutama sang suami. Suami yang bertanggung jawab peran sebagai kepala rumah tangga harus mampu mengayomi keluarganya terutama kepada istrinya.

Berdasarkan data sekunder dari buku kohort Puskesmas Mulyorejo menunjukkan banyak ibu hamil yang memiliki resiko mengalami komplikasi pada kehamilan, saat persalinan, dan nifas antara lain eklampsia, diabetes gestasional, dan anemia. Tujuan dari penelitian ini adalah untuk mengetahui gambaran perilaku suami terhadap perawatan kehamilan ibu hamil di wilayah Kelurahan Mulyorejo tahun 2017.

\section{METODE PENELITIAN}

Penelitian ini menggunakan rancangan cross sectional karena pengumpulan data dilakukan dalam kurun waktu secara bersamaan. Penelitian ini menggunakan pendekatan metode analisis observasional deskriptif fenomena tanpa melakukan suatu analisis.

Jenis penelitian desktriptif yang digunakan bertujuan untuk mengidentifikasi tentang karakteristik suami terhadap perawatan kehamilan ibu hamil dengan melihat gambaran berdasarkan variabel pengetahuan, sikap, dan perilaku. Sumber data yang digunakan untuk penelitian ini adalah data primer. Data primer dengan kuesioner yang mencantumkan beberapa pertanyaan terkait variabel yaitu pengetahuan, sikap, dan perilaku responden dalam perawatan kehamilan. Populasi sasaran dalam penelitian ini adalah para suami dari seluruh ibu hamil yang ada di wilayah Kelurahan Mulyorejo dengan jumlah sebanyak 20 responden yang diperoleh dari buku kohort ibu hamil di Puskesmas Mulyorejo yang dipilih berdasarkan kriteria intrinsik yaitu suami dari ibu hamil dengan usia kehamilan trisemester kedua dan trisemester ketiga. Penelitian ini dilakukan selama 2 bulan yaitu September sampai November 2017. Lokasi penelitian ini yaitu di Kelurahan Mulyorejo Kecamatan Mulyorejo Kota Surabaya. Metode analisis data dilakukan dengan cara menganalisis hasil jawaban kuesioner. Hasil transkrip dianalisis dengan menggunakan tabulasi silang dan frekuensi dari masing-masing kategori yang ditampilkan dalam bentuk tabel.

\section{HASIL PENELITIAN}

Berikut adalah hasil penyajian tabel analisis responden berdasarkan latar belakang karakteristik.

Tabel 1. Karakteristik Suami

\begin{tabular}{lcr}
\hline Karakteristik & Frekuensi & \% \\
\hline Umur Suami & & \\
$22-25$ & 1 & 5 \\
$30-33$ & 9 & 45 \\
$\geq 34$ & 10 & 50 \\
\hline Total & 20 & 100 \\
\hline Pendidikan & Terakhir Suami & \\
SD & 2 & 10 \\
SMP & 5 & 25 \\
SMA & 13 & 65 \\
\hline Total & 20 & 100 \\
\hline Pekerjaan Suami & & \\
PNS & 1 & 5 \\
Swasta & 13 & 65 \\
Wirasawasta & 6 & 30 \\
\hline Total & 20 & 100 \\
\hline Penghasilan Suami & & \\
Tinggi & 1 & 5 \\
Sedang & 14 & 70 \\
Rendah & 5 & 25 \\
\hline Total & 20 & 100 \\
\hline
\end{tabular}

Berdasarkan hasil penyajian karakteristik responden pada Tabel 1 menunjukkan bahwa 
mayaoritas usia suami berada di kelompok usia diatas 34 tahun (50\%). Berdasarkan karakteristik pendidikan mayoritas pendidikan suami berada di kategori SMA (65\%). Berdasarkan tingkat ekonomi pekerjaan suami di Kelurahan Mulyorejo adalah swasta (65\%) dengan tingkat penghasilan sedang (70\%).

Tabel 2. Karakteristik Pengetahuan Suami

\begin{tabular}{lcc}
\hline Pengetahuan & Frekuensi & \% \\
\hline Baik & 4 & 20 \\
Cukup & 14 & 70 \\
Kurang & 2 & 10 \\
\hline Total & 20 & 100 \\
\hline
\end{tabular}

Berdasarkan di tabel 2. tingkat pengetahuan suami di Kelurahan Mulyorejo mayoritas berada dikategori cukup (70\%).

Tabel 3. Karakteristik Sikap Suami

\begin{tabular}{lcc}
\hline Sikap & Frekuensi & \% \\
\hline Baik & 6 & 30 \\
Cukup & 10 & 50 \\
Kurang & 4 & 20 \\
\hline Total & 20 & 100 \\
\hline
\end{tabular}

Berdasarkan tabel 3 sikap suami terhadap perawatan kehamilan setengah dari responden berada dikategori cukup (50\%).

Tabel 4. Karakteristik Perilaku Suami

\begin{tabular}{lcc}
\hline Perilaku & Frekuensi & \% \\
\hline Baik & 4 & 20 \\
Cukup & 13 & 65 \\
Kurang & 3 & 15 \\
\hline Total & 20 & 100 \\
\hline
\end{tabular}

Berdasarkan tabel 4 mengenai perilaku suami terhadap perawatan kehamilan istri sebagian besar berada dikategori cukup dengan jumlah 13 orang (65\%).

Tabel 5. Tabulasi Silang Antara Pengetahuan dan Sikap Suami

\begin{tabular}{|c|c|c|c|c|c|c|c|c|}
\hline \multirow{3}{*}{ Pengetahuan } & \multicolumn{6}{|c|}{ Sikap Suami } & \multirow{2}{*}{\multicolumn{2}{|c|}{ Jumlah }} \\
\hline & \multicolumn{2}{|c|}{ Baik } & \multicolumn{2}{|c|}{ Cukup } & \multicolumn{2}{|c|}{ Kurang } & & \\
\hline & $\mathbf{f}$ & $\%$ & $\mathbf{f}$ & $\%$ & f & $\%$ & $\mathbf{f}$ & $\%$ \\
\hline Baik & 2 & 50 & 1 & 25 & 1 & 25 & 4 & 100 \\
\hline Cukup & 4 & 29 & 8 & 57 & 2 & 14 & 12 & 100 \\
\hline Kurang & 0 & 0 & 1 & 50 & 1 & 50 & 2 & 100 \\
\hline
\end{tabular}

Berdasarkan hasil tabulasi silang antara pengetahuan dan perilaku suami di Kelurahan Mulyorejo mayoritas berada di kategori cukup dengan sebanyak 8 responden (57\%).

Tabel 6. Tabulasi Silang Antara Pengetahuan dan Perilaku Suami

\begin{tabular}{lrrrrrrrr}
\hline & \multicolumn{9}{c}{ Perilaku Suami } & \multirow{2}{*}{ Jumlah } \\
\cline { 2 - 8 } Pengetahuan & \multicolumn{1}{c}{ Baik } & \multicolumn{1}{c}{ Cukup } & \multicolumn{1}{c}{ Kurang } & & \\
\cline { 2 - 8 } & f & \% & f & \% & f & \% & f & \% \\
\hline Baik & 1 & 25 & 3 & 75 & 0 & 0 & 4 & 100 \\
Cukup & 3 & 21,4 & 9 & 64,3 & 2 & 14,3 & 14 & 100 \\
Kurang & 0 & 0 & 1 & 50 & 1 & 50 & 2 & 100 \\
\hline
\end{tabular}

Berdasarkan hasil tabulasi silang antara pengetahuan dan sikap suami Kelurahan Mulyorejo mayoritas berada di kategori cukup dengan sebanyak 9 responden $(64,3 \%)$.

\section{PEMBAHASAN}

\section{Pengetahuan Suami dalam Perawatan Kehamilan Istri}

Tingkat pengetahuan suami di Kelurahan Mulyorejo mayoritas berada dikategori cukup. Pengetahuan akan perawatan kehamilan dapat diperoleh dari lingkungan sekitarnya seperti responden mendapati suami memperlakukan istri dengan memberikan dukungan yang baik, maka responden secara langsung mencerna dan menganalisis perilaku tersebut sehingga responden mendapatkan informasi baru dan menjadikan informasi tersebut sebagai pengetahuan. Hasil dari nilai-nilai pengetahuan terkait perawatan kehamilan adalah suami dapat mengambil keputusan untuk memilih dimana tempat persalinan yang tepat, aman, dan sehat dan dapat ditangani secara langsung oleh tenaga medis bukan dengan dukun bayi atau bukan pada ahlinya, suami mengerti asupan gizi yang diperlukan oleh ibu hamil contoh pemberian vitamin, zat besi, dan asam folat yang memberikan asupan gizi tambahan bagi ibu dan janin dan makan makanan gizi seimbang, suami mengerti bahwa melaksanakan ANC dengan teratur dapat meningkatkan kesehatan ibu dan janin selama kehamilan sampai masa persalinan dan mengerti perkembangan atau masalah yang terjadi selama kehamilan, suami mengerti tanda-tanda bahaya saat kehamilan contoh istri mengalami keluhan yang berlebihan saat hamil lebih baik untuk segera diantarkan ke 
pelayanan kesehatan, dan mengerti pentingnya wanita hamil untuk mengurangi melakukan beban bekerja yang berat.

Pemeriksaan kehamilan dilakukan sesuai dengan dengan usia kehamilan. Pemeriksaan kehamilan dilakukan minimal sebanyak 4 kali selama hamil. Pada trisemester I ibu hamil melakukan pemeriksaan minimal 2 kali, trisemester II minimal $1 \mathrm{kali}$, dan trisemester III minimal 1 kali. Berdasarkan hasil analisis kuesioner ibu hamil di Kelurahan Mulyorejo telah melaksanakan pemeriksaan kehamilan secara teratur. Responden sebagian besar istrinya berada diusia kehamilan trisemester III dimana melakukan pemeriksaan kehamilan minimal 1 kali. Namun sebagian besar ibu hamil melakukan pemeriksaan kehamilan lebih dari 1 kali. Penelitian ini hampir sama dengan penelitian yang dilakukan oleh Lewis, et.al., (2015) di wilayah barat Nepal dengan hasil penelitian yaitu suami memiliki pengetahuan yang cukup baik terkait dengan kehamilan dan persalinan namun masih ada keterbatasan akan pengetahuan tersebut. Banyak suami yang menyadari akan banyak manfaat yang diperoleh ketika memeriksakan kehamilan dan melahirkan di pelayanan kesehatan dan suami lebih memilih istri mereka ditangani secara langsung oleh tenaga medis yang terlatih. Namun kekurangan pengetahuan mereka adalah mengerti tanda-tanda bahaya selama kehamilan, selama persalinan, dan periode postnatal dan neonatal masih kurang. Para suami tersebut menyadari bahwa pentingnya untuk ikut campur tangan akan perawatan kehamilan istri mereka dan mereka mengakui pentingnya akan pemenuhan makanan yang bergizi dan mengurangi perempuan untuk mengurangi beban kerja yang teralalu berat. Namun mereka menyadari akan kurangnya pengetahuan apa yang harus dilakukan, asupan makanan apa yang baik selama kehamilan dan setelah melahirkan, dan bagaimana mengurus hal terebut. Hal ini hampir sama dengan penelitian yang dilakukan oleh Pruthi, et.al., (2016) bahwa hasil penelitian yang dilakukan suami memiliki pengetahuan yang cukup mengenai perawatan kehamilan, namun para suami masih ada yang belum paham akan peran mereka dalam mempraktekkan dan dukungan apa yang akan mereka laksanakan untuk perawatan dan kehamilan.

Pengaruh atau hubungan pengetahuan suami terhadap perawatan kehamilan istri berdasarkan beberapa penelitian sebelumnya terdapat hasil yang bertolak belakang dengan teori Lawrence Green yang menyatakan bahwa perilaku seseorang dalam hal ini partisipasi suami dalam menjaga kesehatan ibu hamil atau melakukan perawatan kehamilan dipengaruhi oleh faktor predisposi yaitu pengetahuan suami terkait perawatan kehamilan dan faktor pendukung yaitu pendidikan suami. Seperti penelitian yang dilakukan sebelumnya oleh Gamelia, et.al. (2013) yang menyatakan bahwa tidak ada hubungan yang signifikan antara pengetahuan dengan perilaku perawatan kehamilan. Meskipun terdapat hasil penelitian yang menyatakan tidak ada hubungan atau pengaruh antara pengetahuan dengan perawatan kehamilan, pengetahuan tetap menjadi hal penting harus dipahami dan dimengerti oleh suami karena suami memiliki tanggung jawab besar akan perawatan kehamilan. Menurut Wardyani (2017) menjelaskan bahwa salah satu cara untuk meningkatkan pengetahuan suami adalah dengan informasi di dalam buku panduan KIA. Buku KIA tersebut memiliki serangkaian informasi mengenai informasi cara merawat kehamilan istri selama masa kehamilan sampai persalinan dan cara merawat bayi.

\section{Sikap Suami dalam Perawatan Kehamilan Istri}

Karakteristik sikap suami terhadap perawatan kehamilan setengah dari responden berada dalam dikategori cukup. hal tersebut dapat disimpulkan bahwa suami cukup dalam memberikan dukungan pada perawatan kehamilan istri. Bentuk Sikap atau dukungan suami dalam perawatan istri berupa suami mengingatkan istri untuk mengikuti anjuran yang diberikan oleh dokter atau bidan, suami mengingatkan istri untuk selalu menjaga pola makan, suami mengingatkan istri untuk menjaga istirahat secara teratur, suami mendukung ibu hamil untuk melakukan olahraga ringan (senam hamil), suami memberikan semangat atau perhatian lebih agar memiliki rasa aman dan bahagia, dan suami dapat menerima perubahan bentuk fisik dari istri. Sikap pada suami memiliki hubungan yang signifikan dengan perawatan kehamilan, hal ini didukung oleh penelitian yang dilakukan oleh Aprina (2017) terdapat hubungan yang signifikan antara sikap dengan partisipasi suami dalam menjaga kesehatan kehamilan istri. Sikap dukungan yang diberikan oleh suami saat istri hamil dapat 
memberikan rasa bahagia dan dapat meningkatkan kesiapan ibu hamil dalam melewati masa-masa kehamilannya sampai masa persalinan. Perawatan kehamilan tidak hanya sekedar bagaimana cara merawat kehamilan secara sehat namun juga mengerti pencegahan komplikasi akibat kehamilan, masa persalinan, dan nifas pada istri jika suami memiliki dukungan sikap yang kurang peduli akan hal tersebut maka kontribusi pada angka kematian ibu karena hal tersebut bersifat. Sedangkan sikap suami yang peduli dan baik akan mengarah kesifat positif ataupun negatif. Mengarah kesifat positif diartikan subyek cenderung akan mendekati objek.

Sikap suami yang memperhatikan perawatan kehamilan istri dapat menambah keharmonisan rumah tangga dengan cara suami memiliki sikap yang lebih perhatian kepada istri. Hal tersebut diungkapkan oleh responden suami yang mengatakan bahwa rumah tangga mereka memiliki kedekatan yang lebih banyak daripada sebelumnya dengan cara mengurangi kegiatan hobi diluar rumah agar bisa selalu dekat dengan istri. Sikap suami yang seperti tersebut juga dapat menumbuhkan rasa kekhawatiran pada kehamilan istri karena suami akan menjadi lebih perhatian dengan perkembangan kehamilan istri mereka. Sikap yang dapat ditunjukkan oleh suami kepada istri saat hamil adalah mereka lebih menjadi penyabar dengan istri, banyak mengalah pada istri, dan berusaha untuk menyenangkan istri mereka selama hamil dengan cara menuruti keinginan istri (ngidam).

Sikap dukungan yang diberikan oleh suami terhadap kehamilan istri akan mempererat hubungan antara suami istri. Sikap suami yang mendukung dalam perawatan kehamilan istri akan membuat istri menjadi lebih tenang dan nyaman akan kehamilannya. Sikap tersebut dapat mewujudkan kehamilan sang istri menjadi lebih sehat. Dukungan suami dapat diartikan sebagai sikap yang penuh perhatian dalam bentuk kontribusi positif dan memberikan dukungan yang positif bagi fungsi emosional dan moral sang istri. Sikap suami dapat mempengaruhi perilaku terhadap kesehatan sang istri.

Sikap memiliki tiga komponen yaitu kepercayaan (keyakinan) mengenai suatu ide atau konsep terhadap objek, kehidupan emosional terhadap objek, adanya kecenderungan melakukan suatu tindakan (Notoadmojo, 2011). Dari ketiga komponen tersebut akan membentuk sikap secara utuh. Pembentukan sikap yang utuh tersebut terkait dengan pengetahuan, cara berpikir, keyakinan, dan emosional. Contoh dari sikap yang utuh dari suami dalam perawatan istri, suami mengetahui sebuah informasi bahwa tingginya angka kematian ibu disebabkan karena buruknya kunjungan ANC ke pelayanan kesehatan. Dari pengetahuan tersebut sang suami akan berpikir untuk mengingatkan ataupun mengajak sang istri untuk rutin melakukan pemeriksaan kehamilan di setiap trisemester. Dalam berpikir tersebut terdapat komponen rasa emosional dan keyakinan yang ikut bekerja. Dengan keyakinan tersebut bahwa jika istrinya melakukan kunjungan perawatan kehamilan secara rutin ke pelayanan kesehatan maka resiko kehamilan dapat segera diatasi bahkan dapat mengurangi masalah kematian ibu. Maka sang suami mempunyai sikap tertentu dalam perawatan kehamilan istri.

Seperti dengan pengetahuan, sikap memiliki tingkatan dimulai dari menerima, merespons, menghargai, bertanggung jawab, dan melakukan tindakan (Notoadmojo, 2011). Suami dapat menerima setiap keluhan kehamilan dari istri selanjutnya suami memberikan respon dengan menanyakan keluahan apa yang dialami oleh istri karena sang istri mengalami keluhan maka suami menanyakan atau mengajak sang istri untuk dibawa ke pelayanan kesehatan. Dalam suatu sikap tidak selalu berakhir dengan tindakan karena untuk mewujudkan suatu sikap menjadi sebuah tindakan diperlukan faktor pendukung atau kondisi yang memungkinkan terpenuhi.

\section{Perilaku Suami dalam Perawatan Kehamilan}

Karakteristik perilaku suami terhadap perawatan kehamilan istri sebagian besar berada dikategori cukup. hal tersebut dapat disimpulkan bahwa suami memberikan perlakuan yang cukup pada perawatan kehamilan istri. Perilaku yang diberikan oleh suami dalam melakukan perawatan kehamilan istri berupa suami mendampingi istri ketika akan memeriksakan kehamilan, suami mengajak ibu jalan-jalan, suami yang merokok tidak merokok berada di dekat ibu hamil, bapak membantu ibu untuk mengerjakan kegiatan rumah tangga yang biasanya dilakukan oleh ibu rumah tangga yaitu suami membantu untuk mencuci piring, membersihkan rumah, membantu ibu memasak, 
dan suami telah mempersiapkan biaya khusus untuk biaya persalinan sang istri. Hasil dari kategori perilaku suami cukup sebanding dengan hasil wawancara dengan suami, ada suami yang mengatakan untuk kegiatan ibu rumah tangga tetap istri yang melakukan pekerjaan tersebut namun ada juga suami yang mengatakan ikut berpatisipasi untuk membantu pekerjaan rumah tangga tersebut dengan tujuan untuk memperingan pekerjaan istri setiap harinya. Suami yang mengantarkan istri untuk periksa kehamilan dinilai cukup hal ini sebanding dengan hasil wawancara dengan bidan Puskesmas Mulyorejo bahwa suami mengantarkan istri untuk pemeriksaan kehamilan namun suami hanya menunggu di ruang tunggu tanpa mendampingi istrinya sehingga sang suami tidak mengerti perkembangan kehamilan istri, lalu ada juga istrinya diantarkan oleh saudara atau sendirian karena suami sedang bekerja hal ini menyebabkan suami memiliki kurangnya informasi mengenai kesehatan maternal sang istri

Menurut Notoadmojo (2011) batasan pengertian dari perilaku adalah suatu kegiatan dari yang bersangkutan. Perilaku mempunyai cakupan kegiatan yaitu berjalan, berbicara, bereaksi, dan lain-lainnyaa. Proses internal seperti berpikir, persepsi, dan emosional dianggap sebagai perilaku manusia. Sehingga dapat disimpulkan bahwa perilaku dapat diamati secara langsung dan tidak langsung. Perilaku dapat timbul karena faktor genetik ataupun faktor lingkungan. Berdasarkan teori yang diungkapkan, perilaku adalah hasil dari hubungan antara perangsang dan suatu tanggapan. Perilaku dalam hal ini suami menanggapi dengan baik akan keinginan istri yang sedang hamil.

Terbentuknya perilaku pada dimulai dari domain kognitif dengan arti subjek akan mengetahui lebih dulu terhadap stimulus objek luar. Selanjutnya subjek akan memiliki pengetahuan baru sehingga ada respon batin dari subjek terhadap objek Namun tidak selalu perilaku didasarkan oleh pengetahuan ataupun sikap yang artinya seseorang tersebut dapat bertindak tanpa mengetahui adanya stimulus terlebuh dahulu dari objek. Suami mengetahui jika istrinya yang sedang hamil membutuhkan bantuan ketika melakukan pekerjaan rumah tangga karena yang dirasa berat, akhirnya secara langsung suami membantu istri untuk melakukan pekerjaan rumah tangga bersamasama untuk memperingan pekerjaan istri.

Perilaku suami dalam berpartisipasi peran ke dalam perawatan kehamilan terrmasuk dalam perilaku kesehatan yaitu tindakan yang berkaitan dengan seseorang dalam memelihara dan meningkatkan kesehatan termasuk tindakan untuk mencegah penyakit (Notoadmojo, 2011).

Menurut H.L Blum dalam Notoadmojo (2011) perilaku memiliki andil nomor dua dalam pelayanan kesehatan. Teori Lawrence Green menjelaskan bahwa perilaku dipengaruhi oleh tiga faktor pokok yaitu predisposisi, faktor pendukung, dan faktor pendorong. Maka dari itu, pendidikan kesehatan sebagai intervensi dari perilaku harus mengarah pada tiga faktor tersebut.

Faktor pendukung berupa sumber-sumber atau fasilitas misal tersedianya alat transportasi untuk mengantarkan istrinya periksa ke pelayanan kesehatan, lalu fasilitas tempat pelayanan kesehatan terdekat untuk memeriksakan kehamilan istri, biaya yang diperlukan untuk pemeriksaan kehamilan. Faktor penguat berupa sikap dan perilaku petugas kesehatan selain sikap dan perilaku suami sebagai penguat istri faktor penguat dari petugas kesehatan juga diperlukan. Petugas kesehatan atau bidan setempat memberikan arahan dan informasi mengenai seputar kehamilan tidak hanya kepada istri namun juga kepada suami.

\section{SIMPULAN DAN SARAN}

\section{Simpulan}

Berdasarkan karakteristik suami di Kelurahan Mulyorejo sebagian besar memiliki pendidikan terkahir di tingkat SMA (65\%) dan sebagian besar bekerja di sektor swasta (65\%) serta kategori penghasilan yang didapatkan berada di kategori sedang (70\%). Peran suami di Kelurahan Mulyorejo pada perawatan kehamilan dinilai berdasarkan karakteristik pengetahuan, sikap, dan perilaku yang seluruhnya mayoritas berada di kategori cukup. Tingkat pengetahuan sebesar $70 \%$, sikap sebesar 50\%, dan perilaku sebesar $65 \%$. Pengetahuan suami cenderung berbanding lurus dengan sikap suami pada perawatan kehamilan istri. Ketika pengetahuan suami baik maka sikap suami pada perawatan 
kehamilan istri akan baik juga, begitu juga dengan sebaliknya.

\section{Saran}

Hasil penelitian ini dapat digunakan sebagai bahan dasar bagi Puskesmas Mulyorejo untuk dapat mengembangkan promosi kesehatan mengenai pentingnya peran keluarga terutama bagi suami dalam melakukan perawatan kehamilan pada istri. Sehingga pengetahuan, sikap, dan perilaku dapat menjadi lebih baik.

\section{DAFTAR PUSTAKA}

Aprina, Nurul, A. 2017. Analisis Faktor yang Berhubungan dengan Partisipasi Suami dalam Menjaga Kesehatan Kehamilan di Wilayah Kerja Puskesmas Gading Rejo Kabupaten Pringsewu. Jurnal Kesehatan, [e-journal] 8 (1): pp. 98-107.

Dinkes Kota Surabaya. 2017. Profil Kesehatan Tahun 2016. Surabaya: Dinas Kesehatan Kota Surabaya.

Gamelia, E., Colti, S., Siti, M. 2013. Determinan Perilaku Perawatan Kehamilan. Jurnal Kesehatan Masyarakat Nasional, [ejournal] 8 (3): pp. 109-114.

Istikhomah, H., Emy, S. 2014 Hubungan antara Pendampingan Suami pada Kunjungan dan dengan Tingkat Kecemasan pada Ibu Hamil Trimester III di BPM Wayan Witri Maguwoharjo, Sleman. Jurnal Kebidanan Indonesia, [e-journal] 5 (2), pp. 32-44.

Kemenkes RI. 2014. Mother's Day: Situasi Kesehatan Ibu. Jakarta: Pusat Data dan
Informasi Kementerian Kesehatan Republik Indonesia.

Kusmiyati, Yuni. 2010. Perawatan Ibu Hamil. Yogyakarta: Fitramaya.

Lewis, S., Andrew, L., Padam, S. 2015. The Role of Husbands in Maternal Health and Safe Childbirth in Rural Nepal: A Qualitative Study. BMC Pregnancy \& Childbirth, [e-journal] 15 (162): pp. 1-10.

Mukaromah, H., Saenun. 2014. Analisis Faktor Ibu Hamil terhadap Kunjungan Antenatal Care di Puskesmas Siwalankerto Kecamatan Wonocolo Kota Surabaya. Jurnal Promkes, [e-journal] 2(1): pp. 39-48.

Notoadmojo, S. 2011. Kesehatan Masyarakat Ilmu \& Seni. Edisi Revisi. Jakarta: Rineka Cipta.

Pruthi, N., Sumitra, B., Vandana, S. 2016. Knowledge, Attitude and Practice Regarding Antenatal Care among Husbands Attending Antenatal Clinic in a Tertiary Care Hospital. The International Journal of Community Medicine and Public Health, [e-journal] 3 (7): pp. 1741-1744.

Saputra, W. 2013. Angka Kematian Ibu (AKI) Melonjak, Indonesia Mundur 15 Tahun. [online] Jakarta: Prakarsa Policy Review.

Usa, W.D.Y.M. 2017. Upaya Penurunan Angka Kematian Ibu (AKI) Di Puskesmas. Jurnal Penelitian Kesehatan Suara Forikes [e-journal] 8 (3): pp. 126-134.

Wardyani, A.P.A.K. 2012. Hubungan antara Pengetahuan Suami dengan Partisipasi Suami dalam Menghadapi Kehamilan dan Persalinan Istri di Kecamatan Polokarto. Skripsi. Universitas Muhammadiyah Surakarta. 